\title{
HISTOPATHOLOGIC STUDY OF CUTANEOUS FIBROSARCOMA IN DOGS (Canis familiares, Linnaeus, 1758) WITH DIFFERENT STAINING TECHNIQUES
}

\author{
Estudo histopatológico de fibrossarcoma cutâneo de cão (Canis familiares, \\ Linnaeus, 1758) com diferentes técnicas de coloração
}

\footnotetext{
Fernanda Trentini Lopes Ribeiro ${ }^{[a]}$, Maria Laura Medeiros Assef ${ }^{[\mathrm{b}]}$, Silvana Maris Círio $^{[\mathrm{c}]}$

[a] Graduada em Biologia pela Pontifícia Universidade Católica do Paraná (PUCPR), Curitiba, PR - Brasil, e-mail: fertrentini@bol.com.br ${ }^{[b]}$ Mestre em Biologia Celulare Molecular pela Universidade Federal do Paraná (UFPR), Curitiba, PR -Brasil, e-mail:laura.assef@pucpr.br ${ }^{[c]}$ Doutora em Ciências Biológicas (Entomologia) pela Universidade Federal do Paraná (UFPR), Curitiba, PR -Brasil, e-mail: silvana.cirio@pucpr.br
}

\begin{abstract}
Fibrosarcoma is characterized as an invasive nodular tumor of mesodermal origin, with elongated normochromatic nuclei. The histopathologic analysis using specific staining techniques is efficient in detailing the neoplastic architecture and the relations with surrounding tissues. In the present study, the canine skin fibrosarcoma was histologically characterized using Hematoxilin-Eosin stain, Mallory's Trichrome stain and Shorr's Trichrome stain as routine staining for conjunctive tissue, Toluidine Blue to highlight the mitosis and Picrosirius-Hematoxilin Trichrome to characterize the collagen type. It was concluded that the Picrosirius stain characterized the existing collagen type as type I and III; the Toluidine Blue staining highlighted the mitoses together with Shorr's staining, as this one also provided a marking for the conjunctive tissue and the formed bands. The Mallory's staining technique highlighted the conjunctive tissue and the bands that are spread; the Hematoxilin-Eosin stain highlighted with emphasis the neoplastic cells.
\end{abstract}

Keywords: Fibrosarcoma. Neoplasm. Cutaneous tumour.

\section{Resumo}

O fibrossarcoma se caracteriza como um tumor nodular invasivo de origem mesodérmica, com núcleos alongados normo e às vezes hipercromáticos. A análise histopatológica possui eficiência em detalhar a arquitetura neoplásica e as relações com os tecidos circundantes, utilizando colorações específicas. No estudo foi caracterizado histologicamente o fibrossarcoma de pele de cão (Canis familiares, Linnaeus, 1758) com as técnicas de coloração de Hematoxilina-Eosina, Tricrômico de 
Mallory e Tricrômico de Shorr como corantes de rotina para tecido conjuntivo, Azul de Toluidina para evidenciar mitoses e Tricrômico de Picrosirius-Hematoxilina para caracterizar o tipo de colágeno existente. Concluiu-se que o Picrosirius-Hematoxilina caracterizou o tipo de colágeno como sendo do tipo I e III; a coloração de Azul de Toluidina evidenciou as mitoses junto com a coloração de Shorr, sendo que esta também proporcionou uma marcação do conjuntivo e dos feixes formados. A coloração de Mallory evidenciou o tecido conjuntivo e os feixes que estão frouxos. A Hematoxilina-Eosina evidenciou as células neoplásicas, com grande ênfase.

Palavras-chave: Fibrossarcoma. Doenças de cães. Tumor cutâneo.

\section{INTRODUCTION}

There has been some time since a more interest in veterinary oncology started, especially in pets, in which a higher occurrence of the disease (MULLER; DALMOLIN, 1970; MOULTON, 1990). The neoplasm can be defined as an abnormal growth of the cells or a secondary growth of the autonomous tissue of progressive character. It appears spontaneously from the affected animal's cells and it is different from normal tissues for its morphological and functional characters. Hence, these cells tend to lose their differentiation as result from uncontrolled cellular proliferation, originating an unbalance in the organism and causing several other factors that cripple the affected animal (BRASILEIRO FILHO, 1998; SANTOS, 1988).

The differences between neoplastic cells and normal cells can be specified in:

1) altered growth properties in vitro and in vivo, displaying irregular proliferation, maturation failure and transplantability;

2) morphological and metabolic alterations related to the differentiation process;

3) karyotypic alterations;

4) antigenic alterations;

5) cell membrane and surface alterations with loss of contact inhibition (CONTRAN et al., 1994).

Benign neoplasms are characterized by united growth and by staying together as an only mass (ALBERTS, 2004). In this kind of tumor, there is no infiltration into adjacent tissues, its growth is expansive, but it may cause compression of organs and neighboring structures. The slow growth enables the formation of blood vessels that nourish the tumor cells (BRASILEIRO FILHO, 1998). In the malignant neoplasms the cells display the capacity to invade neighboring tissues and this invasion usually implies in the ability to escape, enter the blood flow or lymphatic vessels and form secondary foci or metastasis in other parts of the body. When the proliferation of cells exceeds the cell death, the tumor rapidly grows bigger (ALBERTS, 2004). The malignant cells display biochemical and morphological properties different from that of the cells of origin and possessing a high capacity for multiplication, frequent mitotic counts and imprecise lesion limits (BRASILEIRO FILHO, 1998; MIKAELIAN; GROSS, 2002).

However, during the neoplastic cells growth, collagen deposits may occur, mainly of type I, which forms the fibers present especially in the skin, tendons and ligaments, and type III, also called reticular fiber, present in the liver and spleen (JUNQUEIRA; CARNEIRO, 2004), which causes a desmoplastic reaction of the stroma. The collagens are a group of highly characterized proteins, present in all multicellular animals. It is present in high amount in the extracellular matrices and as the main product of fibroblasts (MARTINS; REIS; SILVA, 2003). It is believed that nowadays between $20 \%$ and $75 \%$ of the veterinary attendances in clinics and hospitals are related to neoplasms (SCOTT, 1996). The literature that deals with this subject in domestic animals is relatively expressive and it is where it can be observed that the skin is the main site of neoplasias, especially in dogs (MOULTON, 1990).

According Conceição et al. (2004) and Souza et al. (2001), the attendances have increased in number due to the fact that skin alterations catch the owner's attention, stimulating to seek specialized medical care. According Magalhães et al. (2001), the fibrosarcoma, as well as the other tumors, can be 
diagnosed using two very relevant techniques in veterinary oncology, histopathology and cytopathology, the histopathological analysis bring efficient in detailing the neoplasm architecture and its relations with the surrounding tissues. On the other hand, the cytopathological analysis provides quick and economical diagnosis by punction and immediate fixation, but without any tissue relation and structural detailing.

The increase of neoplasias in animals happens for several reasons, among them the higher longevity observed; balanced nourishment factors; specific protocols and vaccination (DE NARDI et al., 2002; MACEWEN, 1996; MARIA; SOBRAL; DALECK, 1998; WITHROW; MORRISON, 1998).

Fibrosarcoma is characterized as an invasive nodular tumor of mesodermal origin, with elongated central normochromatic nuclei and basophilic nucleoli. Fibromas can turn into fibrosarcomas, through foreign body inflammatory reactions (MIKAELIAN; GROSS, 2002; SOUZA; PARAGUASSU; MOREIRA, 2001).

Thus, the variety of skin tumors described in dogs is quite high, which makes it difficult for the small animal clinicians to know all these conditions. With Hematoxilin-Eosin staining, the fibrosarcomas can be mistaken for another neoplasms, one of them being the leiomyoma or leiomyosarcoma. The use of staining techniques that evidence the conjunctive tissue can this way make the fibrosarcoma diagnosis more specific. This study aims at characterizing histologically the skin fibrosarcoma in dogs (Canis familiares, Linnaeus, 1758), using staining techniques specific for conjunctive tissue and characterizing the type of collagen from the fibrosarcoma through Picrosirius-Hematoxilin Trichrome.

\section{MATERIALS AND METHODS}

Cutaneous fibrosarcoma slides from dogs (Canis familiares, 1758) were analyzed by light microscopy. The neoplasms were supplied by the Veterinary Pathology Laboratory of PUCPR, and the preparation of the slides was carried out at the Cytotechnical Laboratory and at the Experimental Pathology Laboratory from the Campus Curitiba, PUCPR.

The tissue fragments were processed for histopathology according the laboratory's routine protocol using the Hematoxilin-Eosin staining, Shorr's Trichrome, Mallory's Trichrome, PicrosiriusHematoxilin and Toluidine Blue staining (JUNQUEIRA; JUNQUEIRA, 1983).

\section{RESULTS AND DISCUSSION}

All the staining techniques showed the basic pattern of interwoven bundles of primitive fibroblast-like cells with elongated or oval hyperchromatic nuclei, and multiple nucleoli. Histological variations were seen with areas of densely packed swirling spindle cells alternate with areas populated with few cells and dense conjuntive fibers. Fingerprint whorls of spindle cells are seen too (Figures 1, 2 and 3).

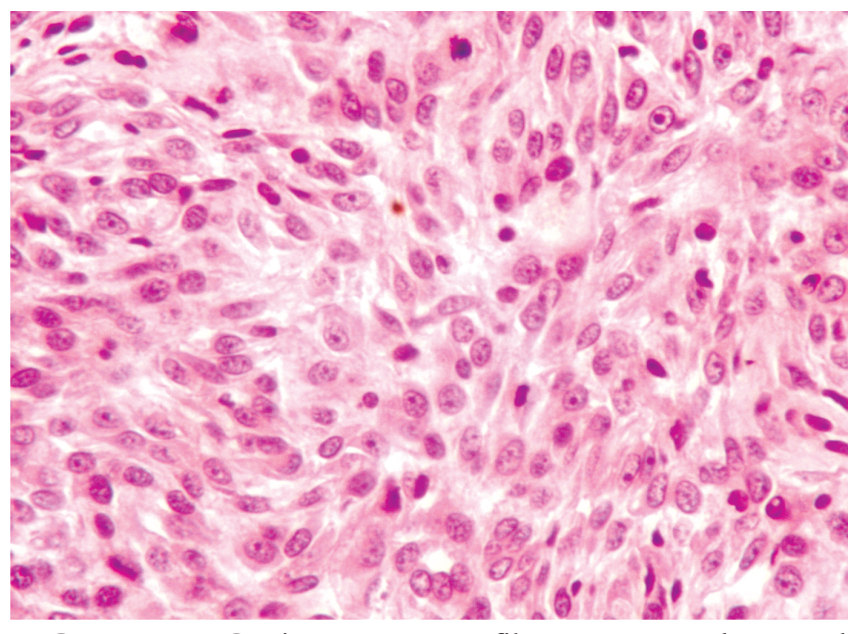

FIGURE 1 - Canine cutaneous fibrosarcoma.Elongated and rounded núcleos. Célls disposed in bandas. HE. Obj. 40x

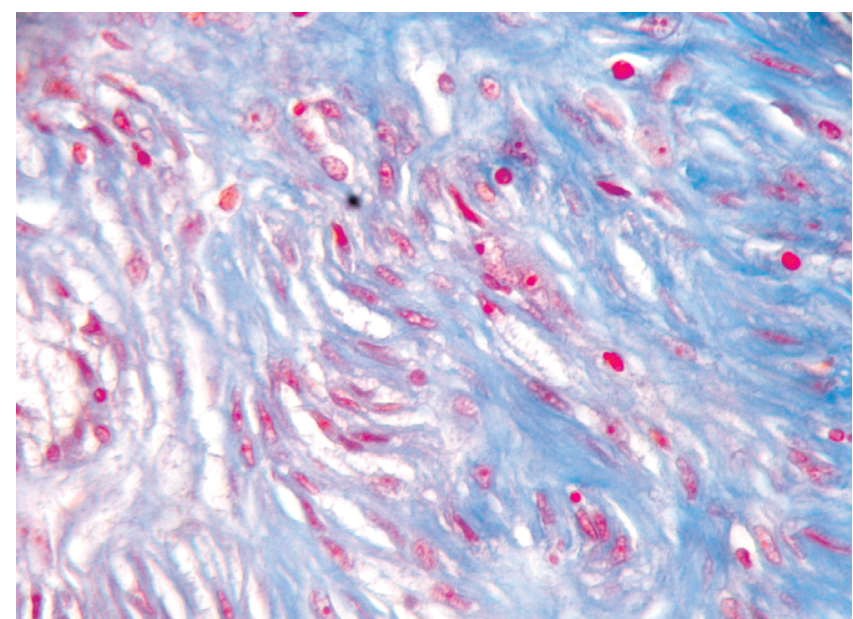

FIGURE 2 - Canine cutaneous fibrosarcoma.Area with dense conjunctive fibers and few fusiform cells. Mallory's. Obj. 40x 


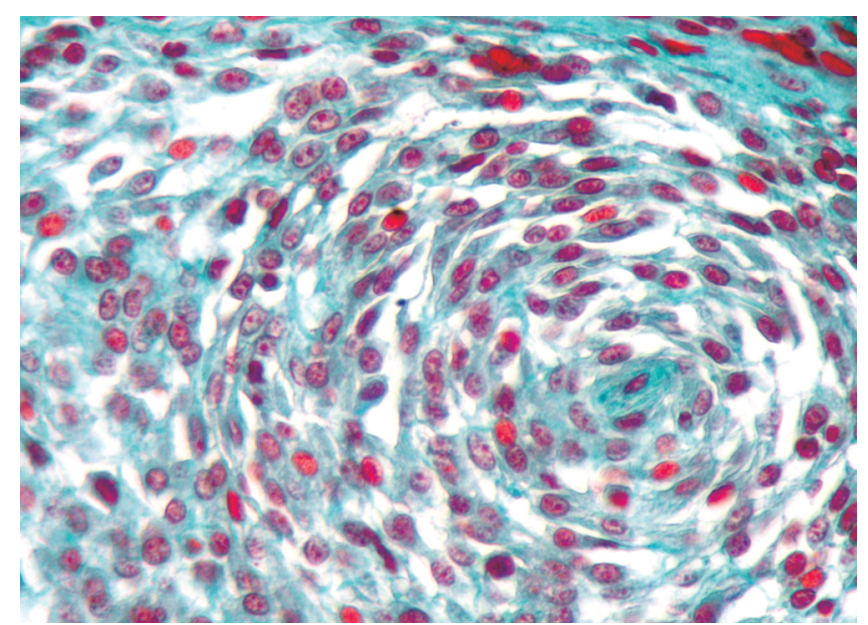

FIGURE 3 - Canine cutaneous fibrosarcoma.Fusiform cells with elongated nuclei disposed in fingerprints whorls. Shorr's. Obj. 40x

The identified collagen was characterized as type I collagen and type III collagen, more evident in peripheral parts of the tissue and in high concentration.

Hematoxilin-Eosin staining (HE) does not clearly show fibrosarcoma evidence. It only characterizes the neoplasm present in the tissue pointing out basic characteristics like good visualization of the nucleus and nucleolus, as well as its structural modifications and staining intensity. Various bands formed by neoplastic cells can also be observed (MAGALHÃES et al., 2001). By our sample shows area with high concentration of neoplastic cells, nuclear hyperchromasia evidenced in the whole visual field, the cells disposed in non-modelled bands with no space failures, caused by more invasive cells, which do not have big nucleoli, only a light structural deformity. The cellular and nuclear pleomorphism is not so evident, but is possible to observe the occurrence of structural alteration (Figure 1). According Martins et al. (2003), lesions with low malignancy are characterized as an area of mild nuclear and cellular pleomorphism and low hyperchromasia. On the other hand, lesions with high malignancy are characterized as areas with large number of pleomorphic cells and nuclei, as well as hyperchromatic nuclei in large quantities. With this, it is possible to balance the three parameters: hyperchromasia, cellular and nuclear pleomorphism. However, this not happen in this study, the cellular and nuclear pleomorphism is not evident, although the hyperchromasia is observed with high intensity. Thus the sarcoma expression in cutaneous tissue may vary in its presentation.

The fields detailed by the Mallory's staining (Figure 2) show variations in the cells density where the amount observed is in low concentration. However, the amount of conjunctive tissue present is quite evident and thus it forms a quite dense area. The cellular and nuclear pleomorphism is strongly evidenced, with fusiform and rounded cells, the reddish cells bring also observed in Figure 2 but they are not strongly characterized. The cells nucleoli are not very evident and have low nuclear hyperchromasia.

When Trichrome stains, Shorr's and Mallory's, are compared some advantages regarding the demonstration of conjunctive tissue, as well as the observed bands that are modeled in a round shape and are disposed in a more organized way in the tissue can be observed as it is seen in Figure 3. In the Shorr's stain the nucleoli are evident and it was also possible to observe the cellular and nuclear pleomorphism which is quite diversified where the rounded cells were evidenced with higher intensity

Toluidine Blue stain presents low capacity of distinction from the conjunctive tissue. According Neves et al. (1993), Magalhães et al. (2001), Rocha, Lorandi e Mendonça (1996), these stain is very important in order to characterize not only factors related to cutaneous carcinoma but also to evidences mastocytes. As shown in Figure 4, the mitoses was observed with more evidence, as well as cellular and nuclear pleomorphism. The chromatin is not well evident by other stain technics. In our routine laboratory, all neoplasias samples are stained with Toluidine Blue for the determination of the mitotic index. 


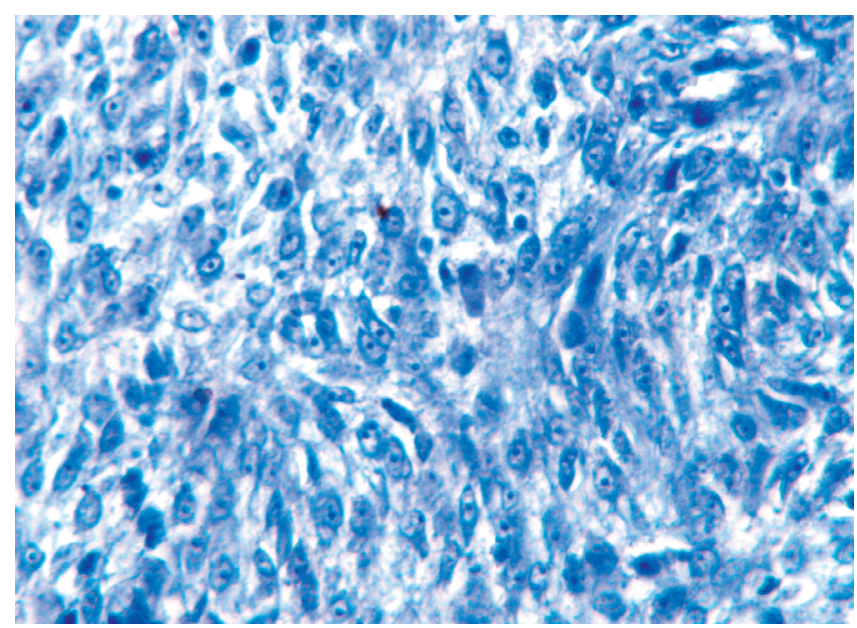

FIGURE 4 - Canine cutaneous fibrosarcoma.Fusiform cells disposed in bands.. Mitosis (circle). Toluidine Blue.Obj. 40x

With Picrosirius staining it is observed that there is little evidence of type III collagen, characteristically present in liver and spleen, according to Martins et al. (2002) and Junqueira e Carneiro (2004). In Figure 5 it is observed that the density of type III collagen is quite low, but there is a large quantity of type I collagen arranged in thick and parallel bands. This disposal is also reported in the study by Martins et al. (2003), where a mild expression of type I collagen occurred, distributed in parallel bands and delimiting areas of tumoral cells. The same tumour area, when not polarized, as seen in Figure 6, is characterized by a strongly stained area, with irregularly disposed cells in the less stained portion and disorganized bands.

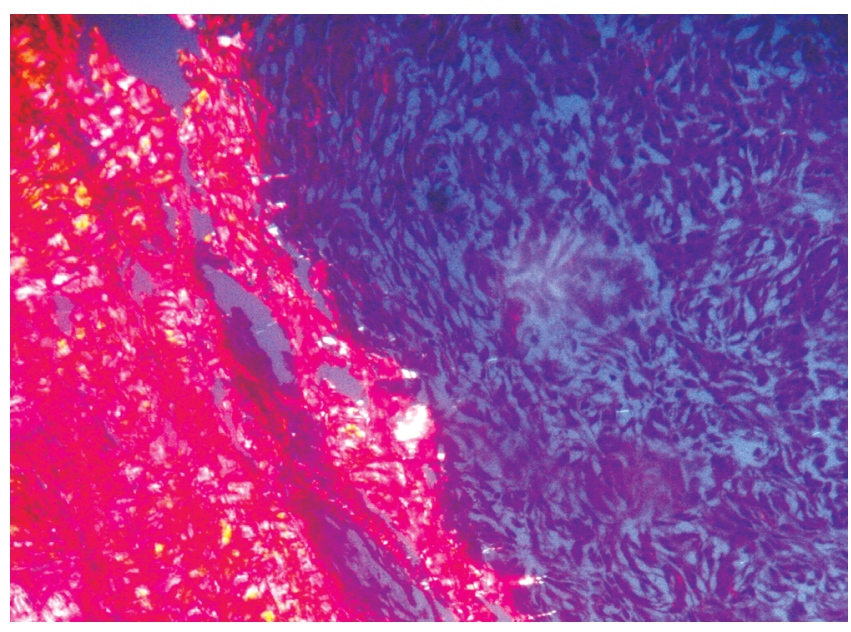

FIGURE 5 - Canine cutaneous fibrosarcoma. Dense type I collagen composition (red) involving area with fusiform cells. Picrosirius under polarization. Obj. 10x



FIGURE 6 - Canine cutaneous fibrosarcoma. The same image (Figure 5) without polarization. Picrosirius. Obj. 10x 
The researches that aim at a better characterization of the conjunctive tissue, cellular and nuclear variations as well as the type of collagen present, will bring important information for a better characterization of the neoplasm, so the attendance to animals affected by neoplasms, whether benign or malignant, will be improved.

Based in the results obtained it was concluded that the different staining techniques can characterize the neoplasm in a better way and diagnose more accurately the type of carcinoma involved. As seen, the Hematoxilin-Eosin stain is not enough to precisely diagnose the fibrosarcoma, because it does not make it clear what the kind of tissue is involved, as well as the composition made by the cells. Hence, it depends on additional techniques like Mallory's Trichrome stain, which has strongly evidenced the conjunctive tissue and the cellular and nuclear pleomorphism; the Shorr's Trichrome stain, that was able not only to improve the evidence of the observed tissue, but also characterize the disposition of bands and the existing mitoses; the Toluidine Blue stain, although used only to evidence mastocytes, was able to precisely diagnose mitosis; and finally the Picrosirius-Hematoxilin Trichrome under polarization, which was essential for the visualization of the existing collagen and the type that was present in the studied neoplasm. However, based on the reported study, it is extremely necessary to have the knowledge of these techniques for the malignant neoplasm diagnosis, because this way the veterinary report will be more precise.

\section{REFERENCES}

ALBERTS, B. Biologia molecular da célula. 3. ed. Porto Alegre: Artes Médicas, 2004.

BRASILERO FILHO, G. Bogliolo patologia geral. 2. ed. Rio de Janeiro: Guanabara Koogan, 1998. CONCEIÇÃO, L. G. et al. Biópsias e histopatologia da pele: um valioso recurso diagnóstico na dermatologia -revisão- parte. Clínica Veterinária, São Paulo, ano 9, p. 36-44, 2004.

CONTRAN, R. S.; KUMAR, V.; ROBBINS, S. L. Robbins-Pathologic basis of diseases. 5th ed. Philadelphia: Saunders, 1994.

DE NARDI, A. B. et al. Prevalência de neoplasias e modalidades de tratamentos em cães, atendidos no Hospital Veterinário da Universidade Federal do Paraná. Arquivos de Ciências Veterinárias, Curitiba, v. 7, n. 2, p. 15-26, 2002.

JUNQUEIRA, L. U.; JUNQUEIRA, L. M. S. Técnicas básicas de histologia e citologia. São Paulo: Santos, 1983.

JUNQUEIRA, L. C.; CARNEIRO, J. Histologia básica. 10. ed. Rio de Janeiro: Guanabara Koogan, 2004.

MAGALHÃES, A. M. et al. Estudo comparativo entre citopatologia e histopatologia no diagnóstico de neoplasias caninas. Pesquisa Veterinária Brasileira, Rio de Janeiro, v. 21, n. 1, p. 23-32, 2001.

MARIA, P. P.; SOBRAL, R. A.; DALECK, C. R. Causística de cães portadores de neoplasias atendidos no Hospital Veterinário da UNESP/ Jaboticabal durante o período de 01/01/95 a 01/ 05/97. In: CONGRESSO BRASILEIRO DE CIRURGIA E ANESTESIOLOGIA VETERINÁRIA, 3., 1998, Belo Horizonte. Anais... Belo Horizonte: UFMG, 1998.

MARTINS, B. G.; REIS, S. R. A. de; SILVA, T. M. C. Expressão do colágeno I em carcinomas epidermóides da cavidade oral. Pesquisa Odontológica Brasileira, São Paulo, v. 17, n. 1, p. 82-88, 2003. 
MARTINS, A. M. R. P. F. da; TAMASO, E.; GUERRA, J. L. Estudo histoquímico de proteínas fibrilares da matriz extracelular em neoplasias mamárias benignas e malignas na espécie canina. Brazilian Journal of Veterinary Research and Animal Science, São Paulo, v. 39, n. 1, p. 43-49, 2002.

MIKAELIAN, I.; GROSS, T. L. Keloidal fibromas and fibrosarcomas in dogs. Veterinary Pathology, Washington, n. 39, p. 149-153, 2002.

MOUlTON, J. E. Tumors in domestic animals. Berkeley: University of California Press, 1990.

MORRISON, W. B. Cancer in dogs and cats: medical and surgical management. Baltimore: Willians; Wilkins, 1998. p. 591-598.

MULLER, S. B. K.; DALMOLIN, C. E. M. P. Incidência de processos neoplásicos em caninos no Estado de São Paulo. Revista de Medicina Veterinária, São Paulo, v. 6, n. 1, p. 65-78, 1970.

NEVES, R. A. et al. Coloração in vivo para diagnóstico de lesões neoplásicas e displásicas da conjuntiva. Arquivo Brasileiro de Oftalmologia, São Paulo, v. 56, n. 6, p. 308-314, 1993.

ROCHA, W. C.; LORANDI, C. S.; MENDONÇA, E. F. de. Uso do azul de toluidina como método auxiliar na detecção de displasias epiteliais e carcinomas da mucosa bucal. Revista Odonto Ciência, Porto Alegre, v. 11, n. 21, p. 27-48, 1996.

SANTOS, J. A. Patologia geral dos animais domésticos: mamíferos e aves. 3. ed. Rio de Janeiro: Guanabara, 1988.

SCOT'T, D. W. Muller \& Kirk, dermatologia de pequenos animais. Rio de Janeiro: Interlivros, 1996.

SOUZA V. T. F.; PARAGUASSU, A. A.; MOREIRA, E. L. T. Ocorrência de neoplasias em caninos na cidade de Salvador- Bahia (Achados de biopsia). Revista Brasileira de Saúde Produção Animal, Salvador, n. 2, p. 53-58, 2001.

WITHROW, S. J.; MACEWEN, E. G. Small animal clinical oncology. 2nd ed. Philadelphia: W. B. Saunders , 1996.

Received: $10 / 04 / 2008$

Recebido: 04/10/2008

Approved: $03 / 20 / 2009$ Aprovado: 20/03/2009 